\title{
PURIFIKASI PROTEIN IMUNOGENIK 31 DAN 56 kDa DARI KELENJAR SALIVA Aedes aegypti
}

\author{
Purification of 31 and 56 kDa Immunogenic Proteins \\ from the Salivary Glands of Aedes aegypti
}

\author{
Syubbanul Wathon, Fitria Muti'ah, Rike Oktarianti, Kartika Senjarini* \\ Jurusan Biologi, Fakultas Matematika dan IImu Pengetahuan Alam, Universitas Jember \\ JIn. Kalimantan No.37, Kampus Tegalboto, Sumbersari, Jember 68121 \\ *Email: senjarini@unej.ac.id
}

\begin{abstract}
The salivary gland of arthropod vector contains various bioactive compounds and plays a role in the transmission of pathogens to the host. The host develops anti-salivary antibodies against vector saliva exposure. Our previous research has identified two immunogenic proteins with molecular weights of 31 and $56 \mathrm{kDa}$ from the Aedes aegypti salivary gland protein extract. However, the role of the 31 and $56 \mathrm{kDa}$ immunogenic proteins from saliva Ae. aegypti is not fully known, so it is necessary to purify two immunogenic protein fractions to better specify the target of developing a dengue vaccine. This study aimed to purify the 31 and 56 $k D a$ immunogenic protein fractions by electroelution and dialysis methods. The purification of the two protein fractions has been successful which were confirmed by the SDS-PAGE by the existence of single-band parallel to the positive control. These results were further supported by the dot blot analysis which showed a positive reaction in the form of dark spots in the two protein fractions which were reacted with dengue patients' serum, endemic healthy people, and neonates. These results indicated that the purified 31 and $56 \mathrm{kDa}$ immunogenic protein fraction can be identified by specific antibodies.
\end{abstract}

Keywords: dialysis, electroelution, immunogenic, purification, saliva

\begin{abstract}
ABSTRAK
Kelenjar saliva vektor arthropoda mengandung berbagai senyawa bioaktif dan berperan dalam transmisi patogen ke tubuh inang. Tubuh inang mengembangkan antibodi anti-saliva terhadap paparan saliva vektor. Penelitian kami sebelumnya telah mengidentifikasi dua protein imunogenik dengan berat molekul 31 dan $56 \mathrm{kDa}$ dari ekstrak protein kelenjar saliva Aedes aegypti. Namun demikian, peranan protein imunogenik 31 dan 56 kDa dari saliva Ae. aegypti belum diketahui sepenuhnya sehingga perlu dilakukan purifikasi dua fraksi protein imunogenik untuk lebih menspesifikkan target pengembangan vaksin dengue. Tujuan penelitian ini untuk melakukan purifikasi fraksi protein imunogenik 31 dan $56 \mathrm{kDa}$ melalui metode elektroelusi dan dialisis. Keberhasilan purifikasi dua fraksi protein 31 dan $56 \mathrm{kDa}$ terbukti dari hasil konfirmasi SDS-PAGE dengan terbentuknya pita tunggal sejajar dengan kontrol positif. Hasil tersebut diperkuat dengan analisis dot blot yang menunjukkan reaksi positif dengan munculnya noktah gelap pada dua fraksi protein tersebut ketika direaksikan dengan serum pasien DBD, penduduk sehat endemik dan neonatus. Hasil ini mengindikasikan bahwa fraksi protein imunogenik 31 dan $56 \mathrm{kDa}$ hasil purifikasi dapat dikenali oleh antibodi spesifik.
\end{abstract}

Kata Kunci: dialisis, elektroelusi, imunogenik, purifikasi, saliva 


\section{PENDAHULUAN}

Demam Berdarah Dengue (DBD) masih menjadi permasalahan kesehatan dunia yang menyebabkan kematian serta morbiditas tinggi. Wabah DBD umumnya terjadi pada beberapa wilayah endemik di negara tropis dan sebagian di wilayah subtropis, terutama di benua Asia dan Amerika (Bhatt et al. 2013). Penyebab penyakit $\mathrm{DBD}$ adalah infeksi virus dengue yang memiliki empat serotipe (DENV-1, DENV-2, DENV-3 dan DENV-4) (Murrell et al. 2011; Sasmono et al. 2018). Serotipe yang ditemukan sering menginfeksi manusia yaitu DENV-2 (Yung et al. 2015). Orang yang berada di wilayah endemik dengue dapat terinfeksi oleh tiga atau bahkan empat serotipe lainnya selama masa hidupnya (Guzman et al. 2010).

Virus dengue menginfeksi tubuh manusia melalui transmisi yang diperantarai oleh vektor nyamuk Aedes aegypti dan Ae. albopictus. Ae. aegypti merupakan vektor primer dari virus dengue karena memiliki habitat di sekitar pemukiman sehingga sering kontak dengan manusia. Sedangkan Ae. albopictus berperan sebagai vektor sekunder virus dengue karena memiliki habitat di lingkungan luar seperti kebun atau hutan yang jauh dari pemukiman manusia (Sim dan Dimopoulos 2010; Wan et al. 2013). Nyamuk tersebut membawa virus dengue setelah mengisap darah dari orang yang terinfeksi kemudian mentransmisikannya ke orang sehat (Almeras et al. 2010). Virus dengue akan masuk dan bereplikasi di dalam sel epitel midgut. Selanjutnya, virus dengue menyebar dari usus ke hemocoel lalu ke bagian tubuh nyamuk yang lain dan akhirnya menuju pada kelenjar saliva (Luplertlop 2014).

Saliva vektor penyakit arthropoda telah diketahui mengandung substansi penting sebagai antihemostasis, antiinflamasi, dan imunomodulator yang berperan dalam proses pengambilan darah pada tubuh inang serta menentukan keberhasilan transmisi patogen ke tubuh inang (Almeras et al. 2010; Vogt et al. 2018). Substansi antihemostasis seperti apyrase mampu mencegah agregasi platelet sehingga dapat menghambat proses pembekuan darah. Substansi vasodilator dapat menyebabkan pelebaran pembuluh darah melalui mekanisme vasodilatasi kapiler darah. Substansisubstansi tersebut dapat mempermudah nyamuk dalam menghisap darah manusia. Komponen antiinflamasi pada saliva nyamuk dapat menyebabkan respon inflamasi untuk melawan molekul saliva menjadi terhalang (Kazimírová dan Štibrániová 2013). Berbeda halnya dengan faktor imunomodulator yang dapat meningkatkan transmisi patogen dengan cara memodulasi respon imun inang sehingga patogen mudah masuk ke dalam tubuh inang (Fontaine et al. 2011). Kemampuan kelenjar saliva vektor dalam mencegah respon hemostasis dan memodulasi respon imun inang menjadi target dalam pengembangan vaksin dengue berbasis vektor. Vaksin berbasis vektor tidak hanya melindungi terhadap patogen yang ditularkan oleh vektor tetapi juga memberikan proteksi terhadap orang lain yang belum terinfeksi (Miller 2010).

Hasil penelitian kami sebelumnya menunjukkan bahwa terdapat dua protein imunogenik dari kelenjar saliva Ae. aegypti dengan berat molekul 31 dan $56 \mathrm{kDa}$ (Oktarianti et al. 2014). Namun demikian, karakterisasi terkait identitas protein serta aktivitas biologis dari kedua protein imunogenik tersebut belum diketahui sepenuhnya. Untuk lebih menspesifikasikan target pengembangan vaksin dengue maka perlu dilakukan penelitian lebih lanjut terhadap kedua protein imunogenik tersebut. Penelitian mengenai identitas protein dan aktivitasnya membutuhkan protein murni sehingga perlu dilakukan purifikasi untuk memperoleh ekstrak murni protein imunogenik 31 dan 56 $\mathrm{kDa}$. Penelitian ini bertujuan untuk melakukan purifikasi protein dengan metode elektroelusi dan dialisis untuk memperoleh ekstrak murni protein imunogenik 31 dan 56 kDa dari kelenjar saliva Ae. aegypti.

\section{BAHAN DAN METODE}

\section{Tempat dan waktu penelitian}

Penelitian ini dilaksanakan di Laboratorium Bioteknologi, Jurusan Biologi, Fakultas Matematika dan IImu Pengetahuan Alam, Universitas Jember pada bulan Januari sampai dengan Juni 2019. 


\section{Pemeliharaan Ae. aegypti}

Pemeliharaan $A e$. aegypti dilakukan di ruang insektarium pada suhu $28^{\circ} \mathrm{C}$ dan kelembaban relatif $60 \%$ yang bertempat di Animal Care Unit, Jurusan Biologi, FMIPA, UNEJ. Nyamuk Ae. aegypti dibiakkan dari larva yang dikoleksi dari wadah/kontainer air di lapangan. Larva dipindahkan ke dalam nampan plastik berisi air untuk dikembangkan menjadi pupa. Selanjutnya, pupa dipindahkan ke cawan pupa dan dimasukkan ke dalam kandang koloni hingga menjadi nyamuk dewasa. Di dalam kandang koloni disediakan larutan sukrosa $10 \%$ sebagai sumber nutrisi nyamuk dan seekor tikus wistar yang diletakkan pada kandang kecil untuk kebutuhan darah yang dihisap nyamuk betina. Selain itu, juga disediakan cawan yang diberi kertas saring pada bibir cawan untuk tempat bertelur nyamuk dewasa.

\section{Identifikasi morfologi Ae. aegypti}

Nyamuk dewasa diambil dari dalam kandang koloni menggunakan aspirator dan diimobilisasi di dalam lemari pendingin pada suhu $-20^{\circ} \mathrm{C}$ selama $1-2$ menit. Proses identifikasi dilakukan dengan menggunakan mikroskop stereo (Olympus, Jepang). Identifikasi morfologi dilakukan untuk membedakan antara spesies nyamuk $A e$. aegypti dan $A e$. albopictus yang sering ditemukan bersamaan ketika koleksi di lapangan. Pengamatan ciri morfologi dilakukan pada bagian mesonotum, mesepimeron, dan femur anterior. Bagian mesonotum pada Ae. aegypti memiliki pola dua garis putih sejajar yang diapit oleh dua garis putih melengkung seperti lyre, sedangkan bagian mesonotum pada $A e$. albopictus hanya terdapat satu garis putih saja. Pengamatan bagian mesepimeron pada $A e$. aegypti dilakukan untuk melihat adanya kumpulan sisik berwarna putih membentuk dua tambalan yang terpisah, sedangkan bagian mesepimeron pada $A e$. albopictus nampak sisik putih yang bergabung menjadi satu. Pengamatan bagian femur anterior pada $A e$. aegypti dilakukan untuk melihat adanya pola garis putih, sedangkan bagian femur anterior pada Ae. albopictus tidak terdapat pola garis putih (Rahayu dan Ustiawan 2013).

\section{Isolasi dan analisis}

Larutan $\mathrm{NaCl} 0,5 \%$ sebanyak $\pm 50 \mu \mathrm{L}$ diteteskan di atas object glass steril sebagai media isotonis untuk menjaga jaringan kelenjar saliva agar tidak lisis selama proses pembedahan. Nyamuk Ae. aegypti betina dibedah dibawah mikroskop stereo (Olympus, Jepang) dengan menggunakan jarum diseksi. Kemudian kelenjar saliva disimpan di dalam larutan $1 \mathrm{mM}$ Phenylmethylsulfonyl Fluoride (PMSF) dalam Phosphate Buffered Saline (PBS) pH 7,4 (Sigma-Aldrict, USA) dan disimpan pada suhu $-20^{\circ} \mathrm{C}$.

Profil protein penyusun kelenjar saliva Ae. aegypti dianalisis dengan metode Sodium Dodecyl Sulphate-Polyacrylamide Gel Electrophoresis (SDS-PAGE). Sampel kelenjar saliva ditambahkan dengan laemmly buffer $(1: 1 \quad(\mathrm{v} / \mathrm{v}))$ kemudian dipanaskan selama 3-5 menit untuk mendapatkan ekstrak protein kelenjar saliva. Kemudian ekstrak protein dimasukkan dalam sumuran gel poliakrilamid yang terdiri dari gel separating $12 \%$ dan gel stacking $4 \%$. Elektroforesis protein dilakukan dengan tegangan listrik $100 \mathrm{~V}$ (constant volt) selama 100 menit pada suhu ruang dan menggunakan buffer elektroda $\mathrm{pH}$ 8,3.

Selanjutnya, dilakukan pewarnaan gel poliakrilamid menggunakan larutan pewarna (staining) Coomassie Brilliant Blue (CBB) (Sigma-Aldrict, USA) selama 60 menit dan dilanjutkan dengan proses pelunturan pewarna sebanyak 3 kali setiap 30 menit dengan menggunakan larutan peluntur warna (destaining) untuk menghilangkan pewarna CBB pada gel poliakrilamid yang tidak berikatan dengan protein. Bagian gel poliakrilamid yang terdapat pita protein target 31 dan $56 \mathrm{kDa}$ dipotong secara aseptis dan disimpan dalam buffer elektroda $\mathrm{pH}$ 8,3 pada suhu $4^{\circ} \mathrm{C}$ sebagai sampel untuk proses purifikasi protein.

\section{Purifikasi}

Potongan gel yang berisi pita protein 31 dan $56 \mathrm{kDa}$ hasil analisis SDS-PAGE dipurifikasi menggunakan metode elektroelusi untuk mengeluarkan protein dari dalam gel poliakrilamid (Vázquez-Iglesias et al. 2017). Elektroelusi dilakukan dengan memasukkan potongan gel yang berisi protein target ke dalam membran selofan (Merck, USA) yang telah berisi buffer elektroda $\mathrm{pH}$ 8,3. Kemudian membran selofan ditutup rapat dan dimasukkan dalam tangki elektroforesis horizontal (Bio-Rad, 
USA) yang berisi buffer elektroda $\mathrm{pH}$ 8,3. Proses elektroelusi dilakukan dengan tegangan listrik $25 \mathrm{~V}$ (constant volt) pada suhu ruang selama 150 menit hingga potongan gel nampak bening. Larutan di dalam membran selofan kemudian dipindahkan ke membran selofan yang baru untuk dilanjutkan ke tahapan dialisis. Dialisis bertujuan untuk menghilangkan kontaminan dan senyawa-senyawa lain yang tidak diperlukan selama proses purifikasi protein (Sattayasai 2012). Membran selofan yang telah berisi larutan hasil elektroelusi kemudian ditutup rapat dan dimasukkan ke dalam gelas kimia yang berisi larutan $\mathrm{PBS} \mathrm{pH}$ 7,4 . Proses dialisis dilakukan pada suhu $4^{\circ} \mathrm{C}$ di atas alat pengaduk (magnetic stirrer) selama 24 jam dan larutan PBS diganti setiap 12 jam sekali. Selanjutnya, larutan hasil dialisis dipekatkan dengan menggunakan microcentrifuge tube dengan Molecular Weigh Cut-Off (MWCO) $10 \mathrm{kDa}$ (Corning, USA). Konsentrasi protein diukur dengan metode Bradford (Sigma-Aldrict, USA) pada panjang gelombang $595 \mathrm{~nm}$. Konfirmasi keberhasilan purifikasi dilakukan dengan metode SDS-PAGE. Sampel protein murni 31 dan $56 \mathrm{kDa}$ ditambahkan dengan laemmli buffer $(1: 1 \quad(\mathrm{v} / \mathrm{v}))$. Elektroforesis dilakukan pada tegangan listrik $100 \mathrm{~V}$ (constant volt) selama 100 menit pada suhu ruang dan menggunakan buffer elektroda $\mathrm{pH}$ 8,3. Selanjutnya, dilakukan pewarnaan gel poliakrilamid menggunakan larutan pewarna CBB selama 60 menit dan dilanjutkan dengan proses pelunturan pewarna sebanyak 3 kali setiap 30 menit.

\section{Analisis imunogenisitas}

Analisis dot blot dilakukan untuk mengetahui adanya reaksi antara antigen dan antibodi yang ditandai dengan munculnya noktah gelap pada membran polyvinylidene fluoride (PVDF) (Merck, USA) (Berger et al. 2015). Potongan membran PVDF direndam di dalam metanol selama 1 menit kemudian direndam di dalam larutan Tris Buffered Saline (TBS) selama 3 menit lalu dikeringanginkan. Sampel protein total sebagai kontrol positif, protein 31 dan $56 \mathrm{kDa}$ hasil purifikasi masing-masing sebanyak 2,5 $\mu \mathrm{L}$ diteteskan tepat di bagian tengah membran dan dibiarkan hingga mengering. Kontrol negatif berupa membran PVDF yang ditetesi dengan larutan PMSF dalam PBS tanpa sampel protein. Membran PVDF kemudian direndam dalam larutan 5\% skim milk dalam TBS pH 7,4 selama 1 jam. Kemudian, membran PVDF dicuci dengan larutan TBS pH 7,4 sebanyak 3 kali, masingmasing 5 menit. Selanjutnya, membran PVDF direndam kembali di dalam larutan 5\% skim milk dalam TBS $\mathrm{pH} 7,4$ yang ditambahkan dengan antibodi primer (perbandingan 1:500 $(\mathrm{v} / \mathrm{v})$ ) selama 2 jam. Antibodi primer yang digunakan yaitu serum darah manusia yang berasal dari pasien DBD, serum orang sehat endemik, dan neonatus. Protokol koleksi serum darah manusia telah disetujui oleh Komite Etik, Fakultas Kedokteran Gigi, Universitas Jember (No. 148/UN25.8/KEPK/DL2018). Masing-masing membran PVDF dicuci dengan larutan TBS $\mathrm{pH}$ 7,4 sebanyak 3 kali, masing-masing 5 menit. Kemudian membran PVDF direndam di dalam larutan 5\% skim milk dalam TBS pH 7,4 yang telah ditambahkan antibodi sekunder (Anti-Human IgG) (Rockland, USA) dengan perbandingan $1: 5000(\mathrm{v} / \mathrm{v})$ selama 2 jam. Kemudian masing-masing membran PVDF dicuci dengan larutan TBS $\mathrm{pH} 7,4$ sebanyak 3 kali, masing-masing 5 menit lalu dikeringanginkan dan diwarnai dengan Nitroblue Tetrazolium Chloride (NBT) / 5Bromo-4-Chloro-3-Indolyl-Phosphate (BCIP) (Rockland, USA) untuk visualisasi adanya ikatan antara sampel protein murni dengan antibodi.

\section{HASIL DAN PEMBAHASAN}

\section{Identifikasi morfologi Ae. aegypti}

Nyamuk Ae. aegypti hidup dan berkembang di lingkungan yang dekat dengan pemukiman penduduk, seperti tempat penampungan air bersih di dalam atau di luar rumah (Hodijah et al. 2015). Hal ini yang menyebabkan Ae. aegypti mudah dalam menjangkau manusia untuk menghisap darah dan menjadi vektor primer dalam penyebaran virus dengue (Farnesi et al. 2012). Berbeda halnya dengan vektor sekunder penyebaran virus dengue yaitu $A e$. albopictus yang lebih menyukai hidup di lingkungan luar rumah atau bangunan misalnya di perkebunan yang rimbun dengan pepohonan (Boesri 2011). Adanya perilaku Ae. aegypti dan Ae. albopitus dalam menghisap darah berulang pada manusia, maka hal ini juga semakin meningkatkan 
peluang transmisi virus dengue (Farjana dan Tuno 2013).

Karakteristik bagian tubuh Ae. aegypti dan $A e$. albopictus yaitu berwarna gelap atau hitam dengan bintik-bintik sisik berwarna putih pada beberapa bagian tubuh, kaki dan sayap (Sucipto 2011). Namun demikian, terdapat perbedaan yang terlihat jelas pada ciri morfologi antara nyamuk Ae. aegypti dan Ae. albopictus. Beberapa perbedaan tersebut dapat dilihat pada bagian mesonotum, mesepimeron, dan femur anterior. Bagian
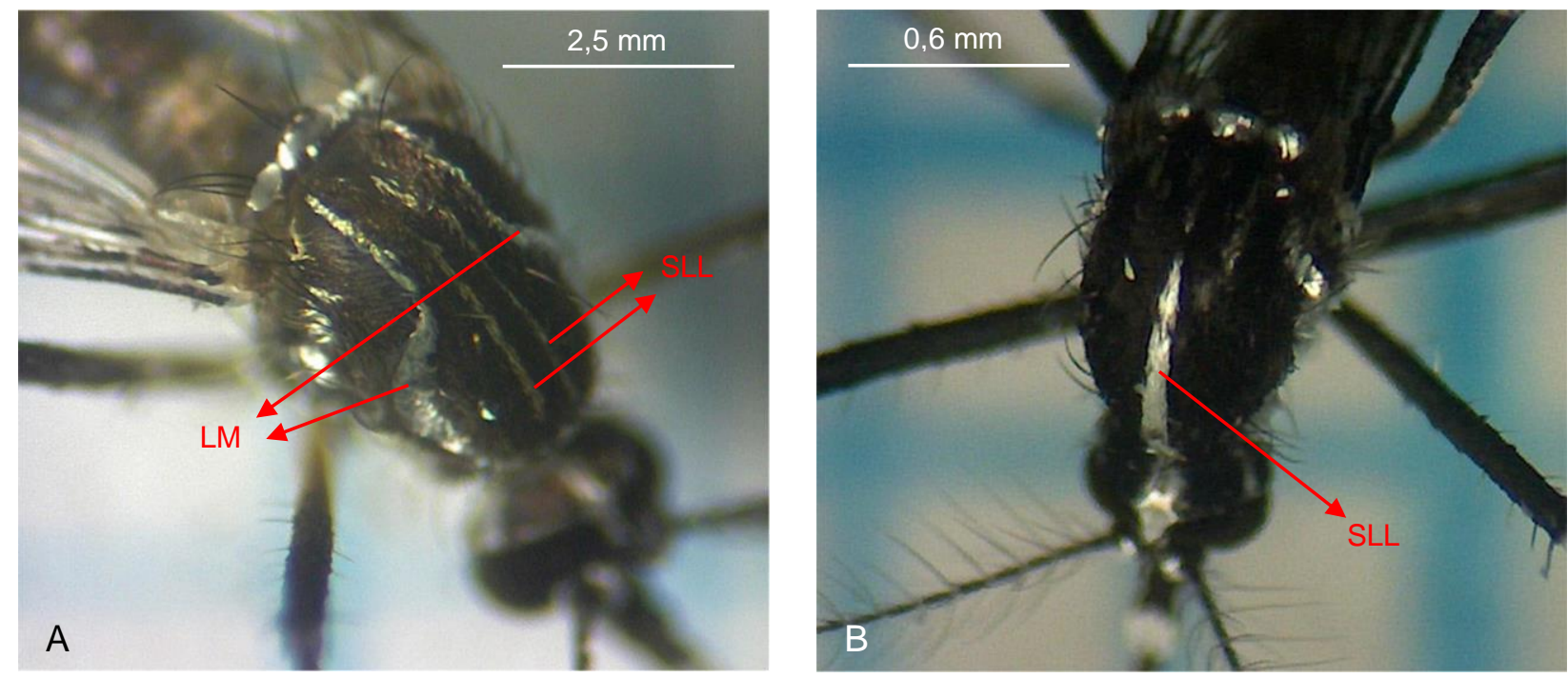

Gambar 1. Perbedaan mesonotum pada Ae. aegypti (A) dan Ae. albopictus (B), Lyre Marking (LM), SSL (Submedian Longitudinal Line) (Olympus stereo mikroskopi, perbesaran 20×, kamera: OptiLab)
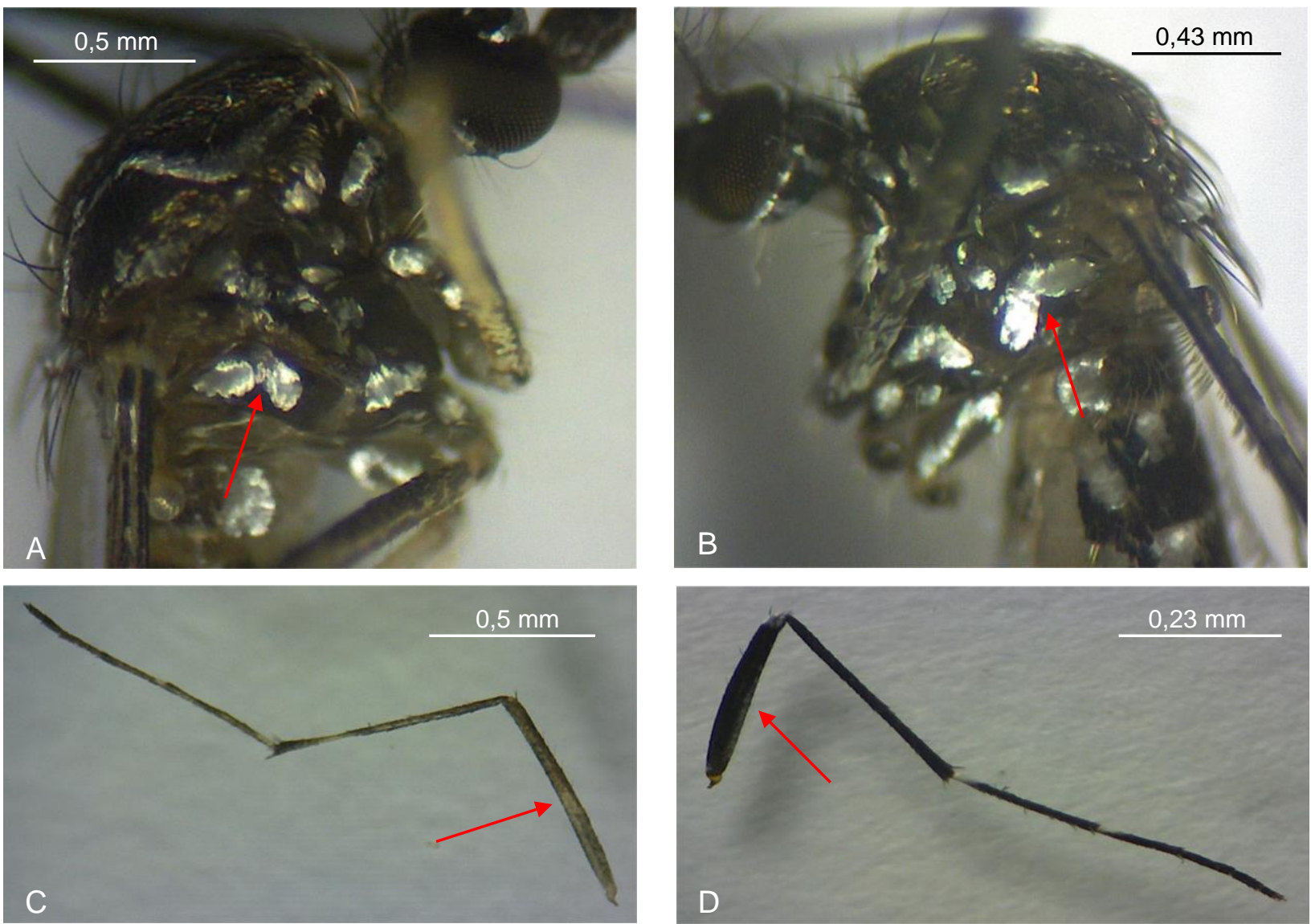

Gambar 2. Perbedaan mesepimeron pada Ae. aegypti (A) dan Ae. albopictus (B); femur anterior pada Ae. aegypti (C) dan Ae. albopictus (D) (Olympus stereo mikroskopi perbesaran 20×, Kamera: Optilab) 
mesonotum pada Ae. aegypti memiliki deretan rambut putih yang membentuk pola sepasang garis putih lurus yang sejajar dan diapit oleh sepasang garis melengkung, sedangkan bagian mesonotum pada $A e$. albopictus hanya memiliki satu pola garis putih lurus (Zettel dan Kaufman 2013). Perbedaan bagian mesonotum pada $A e$. aegypti dan Ae. albopictus dapat dilihat pada Gambar 1. Bagian mesepimeron pada Ae. aegypti memiliki dua tambalan sisik putih yang yang terpisah, sedangkan mesepimeron

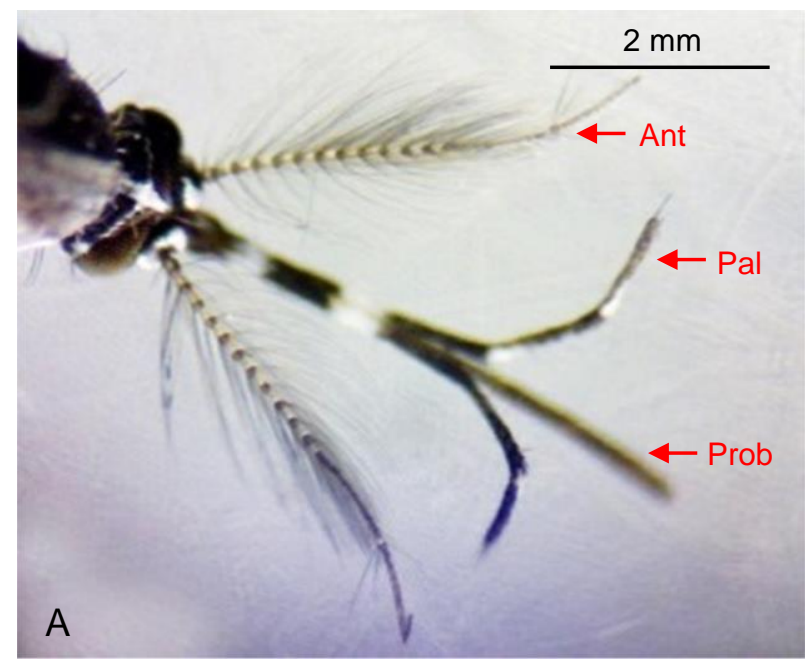

pada Ae. albopictus memiliki dua tambalan putih yang menyatu. Bagian femur anterior pada $A e$. aegypti memiliki deretan rambut putih yang membentuk pola garis putih lurus, sedangkan pada seluruh bagian femur anterior Ae. albopictus hanya memiliki rambut hitam (Andrew dan Bar 2013; Rahayu dan Ustiawan 2013). Perbedaan bagian mesepimeron dan femur anterior pada $A e$. aegypti dan Ae. albopictus dapat dilihat pada Gambar 2.

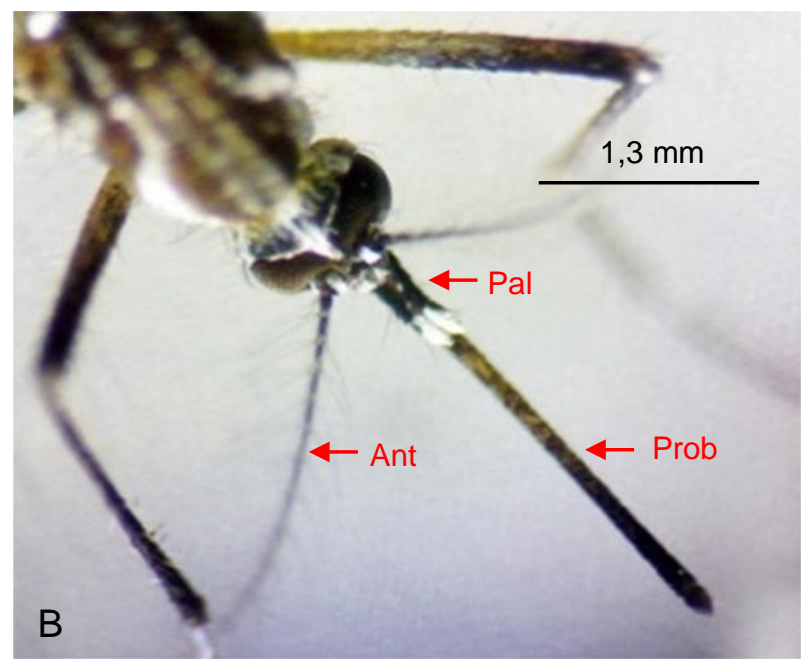

Gambar 3. Perbedaan antena (Ant), proboscis (Prob), dan maxillary palpus (Pal) pada Ae. aegypti jantan (A) dan Ae. aegypti betina (B) (Olympus stereo mikroskopi, perbesaran 40x, kamera: OptiLab)
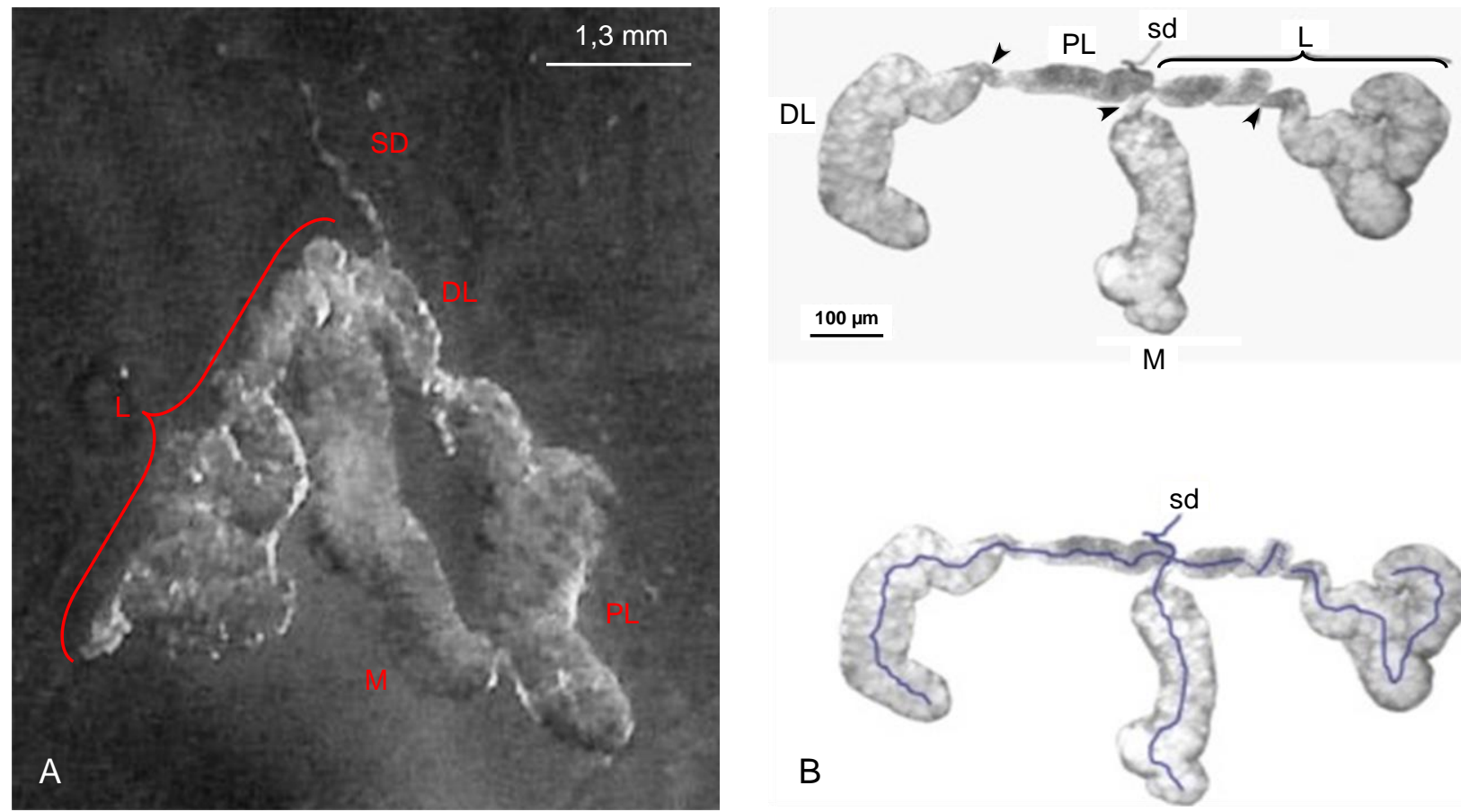

Gambar 4. Struktur morfologi kelenjar saliva Ae. aegypti betina. (A) Tersusun atas salivary duct (sd), lobus Medial (M), lobus Lateral (L), lobus Proximal-Lateral (PL), dan lobus Distal-Lateral (DL) (Mikroskop LW Scientific, perbesaran 400×, kamera: OptiLab). (B) Struktur kelenjar saliva Ae. aegypti betina (Juhn et al. 2011) 
Ae. aegypti jantan dan betina memakan nektar tanaman sebagai sumber nutrisi. Selain itu, Ae. aegypti betina juga membutuhkan darah manusia sebagai nutrisi untuk pematangan telurnya, sehingga hal ini memainkan peran penting dalam transmisi patogen dan mengontrol salivasi nyamuk terhadap inang (Juhn et al. 2011). Ae. aegypti betina memiliki perbedaan ciri morfologi dengan $A e$. aegypti jantan (dimorfisme seksual) yaitu pada bagian antena, proboscis dan maxillary palpus. Ae. aegypti memiliki antena dengan 13 segmen dan di antara segmen terdapat rambut-rambut yang tersusun melingkar. Ukuran pada antena Ae. aegypti jantan lebih panjang dan memiliki rambut antena lebih banyak (tipe plumose). Sedangkan antena Ae. aegypti betina lebih pendek dan memiliki rambut antena yang lebih sedikit (tipe pilose). Selain itu, perbedaan diantara keduanya terletak pada proboscis dan maxillary palpus. Bagian proboscis pada Ae. aegypti betina berbentuk silindris, berwarna hitam dan ukurannya lebih panjang dibanding dengan maxillary palpus. Sedangkan, ukuran proboscis pada Ae. aegypti jantan memiliki panjang yang relatif sama dengan maxillary palpus. Terdapat 5 segmen pada maxillary palpus Ae. aegypti jantan dengan bercak warna putih pada setiap segmen. Ukuran maxillary palpus pada Ae. aegypti betina lebih pendek dibandingkan dengan Ae. aegypti jantan. Selain itu, terdapat bercak putih pada bagian ujung maxillary palpus Ae. aegypti betina (Andrew dan Bar 2013). Perbedaan bagian antena, proboscis dan maxillary palpus dapat dilihat pada Gambar 3.

\section{Isolasi dan analisis}

Isolasi kelenjar saliva Ae. aegypti dilakukan dengan teknik mikrodiseksi yaitu metode pembedahan tubuh nyamuk yang dilakukan dibawah mikroskop untuk memisahkan kelenjar saliva Ae. aegypti dari bagian tubuh nyamuk lainnya (Schmid et al. 2017). Pada proses mikrodiseksi, tubuh nyamuk diletakkan di atas tetesan larutan $0,5 \% \mathrm{NaCl}$. Hal ini dilakukan untuk menjaga agar sel dan jaringan pada kelenjar saliva yang telah diisolasi tidak mengalami lisis karena larutan $0,5 \% \mathrm{NaCl}$ bersifat isotonis dengan cairan di dalam tubuh serangga
(Barbosa et al. 2015). Penyimpanan jaringan kelenjar saliva pada larutan PMSF dalam PBS yang berfungsi sebagai penghambat aktivitas beberapa protease, sehingga diharapkan protein kelenjar saliva tidak terdegradasi oleh adanya protease (Bano et al. 2014).

Kelenjar saliva Ae. aegypti betina memiliki beberapa fungsi penting untuk kelangsungan hidupnya (Luplertlop 2014), karena mensekresikan molekul bioaktif untuk efisiensi selama proses mengisap darah manusia (de Melo et al. 2015). Berdasarkan struktur dan fisiologisnya, kelenjar saliva nyamuk menjadi organ penting untuk mengatasi ketahanan fisik dan hemostatik pada tubuh inang (manusia). Peran penting lainnya yaitu menghalangi respon imun atau inflamasi inang untuk keberhasilan menentukan lokasi injeksi pada saat pengambilan darah dan transmisi patogen (Urdaneta-Marquez dan Failloux 2011).

Struktur morfologi kelenjar saliva $A e$. aegypti bertipe acinus (Ribeiro et al. 2016) terdiri atas enam lobus yang tersusun sepasang dan terhubung oleh saluran utama yang disebut Salivary Duct (SD) (Raquin dan Lambrechts 2017). Lobus tersebut terdiri dari tiga bagian yang sama yaitu dua lobus lateral (Lateral lobes (L)) dengan ukuran yang identik dan terletak dipinggir serta satu lobus di tengah (Medial (M)) dengan bentuk lebih pendek dan lebar. Lobus lateral tersusun atas dua bagian yaitu Proximal-Lateral (PL) dan Distal-Lateral (DL) (Juhn et al. 2011). Struktur kelenjar saliva Ae. aegypti dapat dilihat pada Gambar 4.

Secara histologi, bagian-bagian dari kelenjar saliva Ae. aegypti mensekresikan protein yang berbeda (Wasinpiyamongkol et al. 2010). Pada bagian lobus proksimal (Proximal-Lateral) memproduksi protein yaitu alpha-glucosidase, lisozim, amilase 1, salivary chymotrypsin-like, V-ATPase, carbonic anhydrase, gambicin, dan serine protease. Pada bagian lobus distal (DistalLateral) mempoduksi protein D7, $30 \mathrm{kDa}$ allergen-like protein, dan aegyptin. Sedangkan pada lobus medial memproduksi protein sialokinin, angiopoietin-like, dan putative C-type lectin. Lobus medial dan lobus distal juga memproduksi protein yang sama yaitu serpin, salivary apyrase, D7, salivary purine nucleosidase (Juhn et al. 2011). 
Hasil analisis profil protein dari ekstrak protein total kelenjar saliva Ae. aegypti dengan metode SDS-PAGE menunjukkan adanya dua pita protein target dengan berat molekul 31 dan 56 kDa (Gambar 5). Berdasarkan penelitian yang dilakukan oleh Oktarianti et al. (2014), diketahui bahwa protein dengan berat molekul 31 dan $56 \mathrm{kDa}$ terdeteksi bersifat imunogenik yang berarti dapat memodulasi respon imun manusia yang tinggal di daerah endemik DBD. Oleh karena protein 31 dan $56 \mathrm{kDa}$ diduga berperan penting dalam modulasi respon imun inang terhadap paparan saliva $A e$. aegypti, maka selanjutnya dilakukan purifikasi protein untuk menspesifikkan pengujian imunogenesitas dari kedua protein tersebut.

M

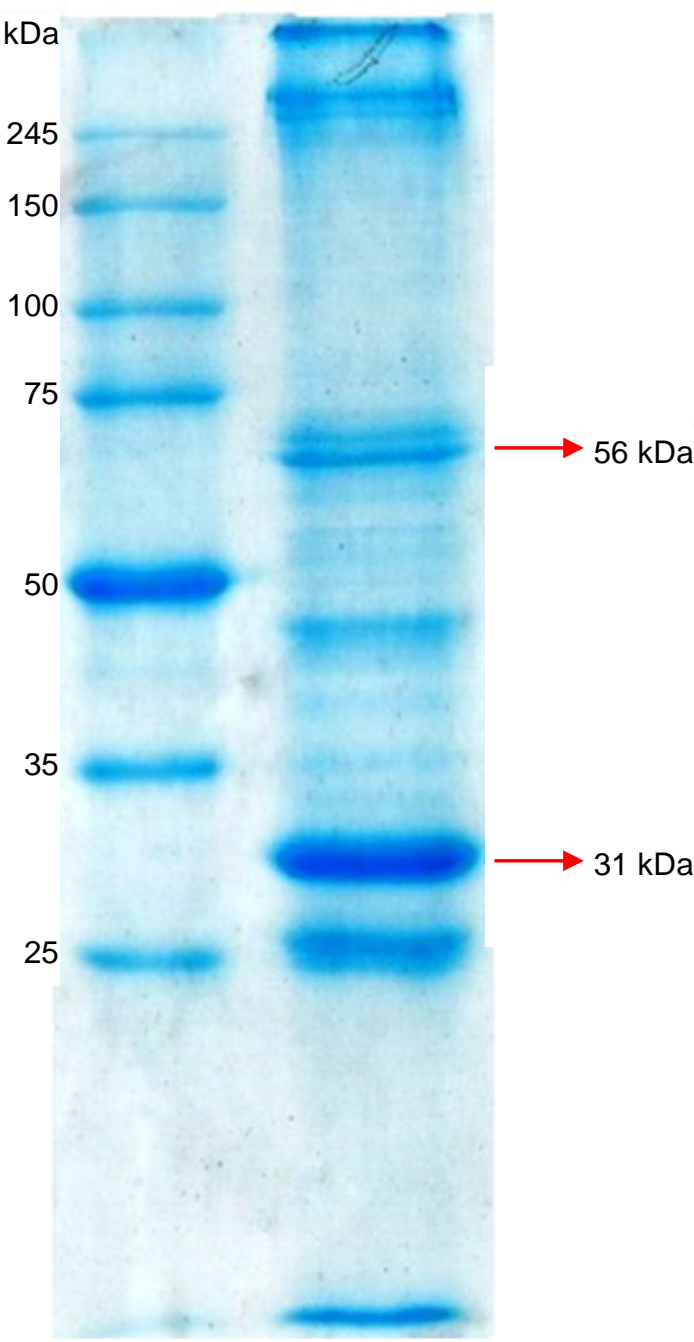

Gambar 5. Profil protein total kelenjar saliva/ salivary gland (SG) Ae. aegypti, marker protein (Promega V8491) (M) (Scanner Canon MP287)

\section{Purifikasi}

Purifikasi protein merupakan proses pemurnian protein untuk mendapatkan protein murni dalam jumlah yang banyak dari suatu sampel. Protein murni didapatkan dengan cara menghilangkan komponen non target atau kontaminan sehingga didapatkan protein murni untuk dianalisis lebih lanjut (Hedhammar et al. 2010). Purifikasi protein dapat menggunakan teknik kromatografi maupun non-kromatografi. Teknik pemurnian protein non-kromatografi yang umum digunakan adalah metode elektroelusi karena teknik tersebut tidak membutuhkan peralatan yang rumit, proses pemurnian protein yang lebih cepat serta relatif mudah dilakukan (SaPereira et al. 2000).

Purifikasi protein imunogenik 31 dan 56 kDa dilakukan dengan metode elektroelusi dan dialisis. Metode elektroelusi bertujuan untuk mengeluarkan protein target dari dalam gel poliakrilamid sehingga didapatkan protein murni yang diinginkan (Vázquez-lglesias et al. 2017). Potongan gel poliakrilamid yang didalamnya terdapat protein target ditempatkan ke dalam membran selofan yang berisi buffer elektroda. Protein target tetap berada pada membran selofan karena ukuran pori membran (14 kDa) lebih kecil dari pada ukuran protein target 31 dan $56 \mathrm{kDa}$. Pergerakan protein keluar dari gel poliakrilamid dibantu dengan tegangan listrik selama proses elektroelusi. Tegangan listrik dan waktu yang diperlukan selama proses elektroelusi bergantung pada ukuran protein target dan konsentrasi gel poliakrilamid (Burgess 2009). Berdasarkan hasil optimasi, proses elektroelusi protein target 31 dan 56 $\mathrm{kDa}$ berhasil dilakukan dengan menggunakan tegangan listrik $25 \mathrm{~V}$ selama 150 menit. Purifikasi protein kemudian dilanjutkan dengan proses dialisis untuk menghilangkan kontaminan yang masih bercampur dengan protein target (Bhaskar et al. 2008). Prinsip kerja dialisis adalah pergerakan acak molekul atau partikel di dalam zat pelarut dari larutan dengan konsentrasi tinggi ke larutan dengan konsentrasi yang lebih rendah melalui membran semipermeabel (Haney et al. 2013).

Hasil dari proses dialisis kemudian dipekatkan menggunakan microcentrifuge tube MWCO $10 \mathrm{kDa}$ untuk menghilangkan molekul-molekul seperti garam penyusun 
buffer dengan berat molekul dibawah $10 \mathrm{kDa}$ sehingga diperoleh protein murni dengan konsentrasi yang lebih tinggi. Konsentrasi protein $31 \mathrm{kDa}$ adalah $0,47 \mu \mathrm{g} / \mu \mathrm{L}$ dan protein $56 \mathrm{kDa}$ yaitu $0,44 \mu \mathrm{g} / \mu \mathrm{L}$ yang kemudian dikonfirmasi secara visual dengan metode SDS-PAGE untuk memastikan bahwa protein 31 dan $56 \mathrm{kDa}$ telah berhasil dimurnikan.

Berdasarkan hasil konfirmasi purifikasi protein dengan metode SDS-PAGE, terlihat bahwa fraksi protein 31 dan $56 \mathrm{kDa}$ telah berhasil dimurnikan (Gambar 6). Terlihat pita tunggal protein 31 dan $56 \mathrm{kDa}$ yang sejajar dengan kontrol positif yaitu protein $31 \mathrm{kDa}$ dan $56 \mathrm{kDa}$ dari ekstrak total kelenjar saliva $A e$. aegypti. Salah satu kriteria protein yang berhasil dimurnikan akan terbentuk pita tunggal setelah dikonfirmasi melalui analisis SDS-PAGE (Ahmad 2012).

\section{Analisis imunogenisitas}

Fraksi protein 31 dan $56 \mathrm{kDa}$ dari kelenjar saliva Ae. aegypti yang telah berhasil dimurnikan perlu dikonfirmasi lebih lanjut untuk menguji aktivitas imunogenisitasnya dengan metode dot blot. Analisis dot blot pada protein total, protein imunogenik 31 dan $56 \mathrm{kDa}$ menggunakan tiga macam sampel serum manusia sebagai antibodi primer yaitu sampel serum pasien DBD, serum orang sehat di daerah endemik, dan serum neonatus yang diambil dari tali pusar bayi yang baru lahir. Hasil penelitian Oktarianti et al. (2014), menunjukkan bahwa orang yang tinggal di daerah endemik DBD memiliki respon antibodi spesifik terhadap protein imunogenik 31 dan $56 \mathrm{kDa}$ dari kelenjar saliva Ae. aegypti yang tidak dimiliki oleh orang yang tinggal di daerah non-endemik DBD dan neonatus.

Hasil analisis dot blot menunjukkan terbentuknya noktah gelap pada membran yang menandakan adanya ikatan antara antigen dan antibodi (Gambar 7). Hal ini menunjukkan bahwa protein total, fraksi protein $31 \mathrm{kDa}$ dan $56 \mathrm{kDa}$ dari kelenjar saliva Ae. aegypti dapat terdeteksi oleh sampel serum pasien DBD, serum orang sehat endemik, dan serum neonatus walaupun lebih tipis. Hasil positif pada serum neonatus disebabkan oleh antibodi (lgG) yang dimiliki bayi baru lahir diperoleh secara pasif dari sang ibu (maternal antibody) yang pernah terpapar nyamuk $A e$. aegypti walaupun dalam kadar yang rendah (Chau et al. 2009).

Ketebalan warna pada hasil analisis menunjukkan adanya ikatan yang kuat antara antigen dan antibodi. Noktah gelap yang terbentuk pada sampel protein total kelenjar saliva Ae. aegypti (kontrol positif) yang

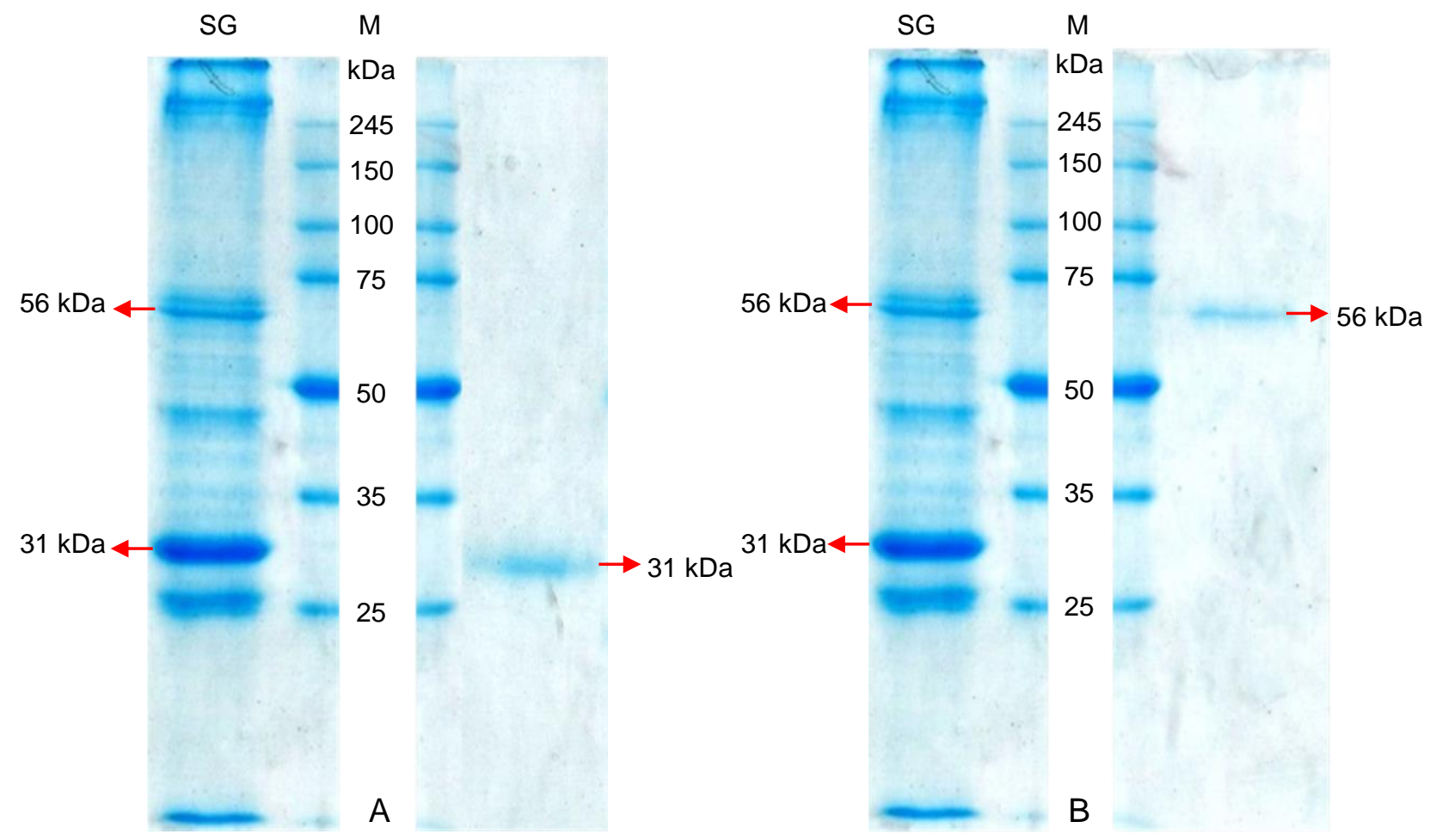


direaksikan dengan sampel serum pasien DBD dan sampel serum orang sehat yang tinggal di daerah endemik nampak dengan ketebalan yang relatif sama. LondonoRenteria et al. (2013) menyatakan bahwa orang yang tinggal di daerah endemik memiliki respon imun yang membentuk antibodi spesifik karena kemungkinan seringnya terkena paparan saliva vektor.

Noktah gelap yang juga terbentuk pada sampel fraksi protein 31 dan $56 \mathrm{kDa}$ hasil purifikasi yang terdeteksi oleh ketiga sampel serum menunjukkan adanya reaksi positif antara antigen dan antibodi. Protein $31 \mathrm{kDa}$ memiliki komponen utama D7 (Oktarianti et al. 2014) yaitu protein yang paling banyak disekresikan pada kelenjar saliva Ae. aegypti betina. Hal ini memungkinkan inisiasi respon antibodi spesifik pada orang yang tinggal di daerah endemik (Oktarianti et al. 2015). Protein D7 merupakan protein yang mampu

berikatan dengan amina biogenik seperti serotonin, histamin, dan norepinefrin pada inang. Ikatan tersebut bersifat antagonis terhadap aktivitas hemostasis inang yaitu vasokonstriksi dan agregrasi platelet sehingga dapat memfasilitasi nyamuk untuk menghisap darah manusia dan transmisi patogen (Oktarianti et al. 2015). Sedangkan protein $56 \mathrm{kDa}$ memiliki komponen utama apyrase yang disekresikan pada saat nyamuk menghisap darah yang juga memodulasi respon imun inang (Oktarianti et al. 2015). Apyrase atau ATP-diphosphohydrolase merupakan enzim yang dapat mengubah ATP atau ADP menjadi AMP dan ortofosfat. Penurunan ADP dapat menghalangi agrerasi platelet sehingga memudahkan nyamuk untuk memperoleh darah saat menghisap darah manusia (Dong et al. 2012).

Reaksi positif dari kedua fraksi protein 31 da 56 kDa hasil purifikasi terhadap ketiga
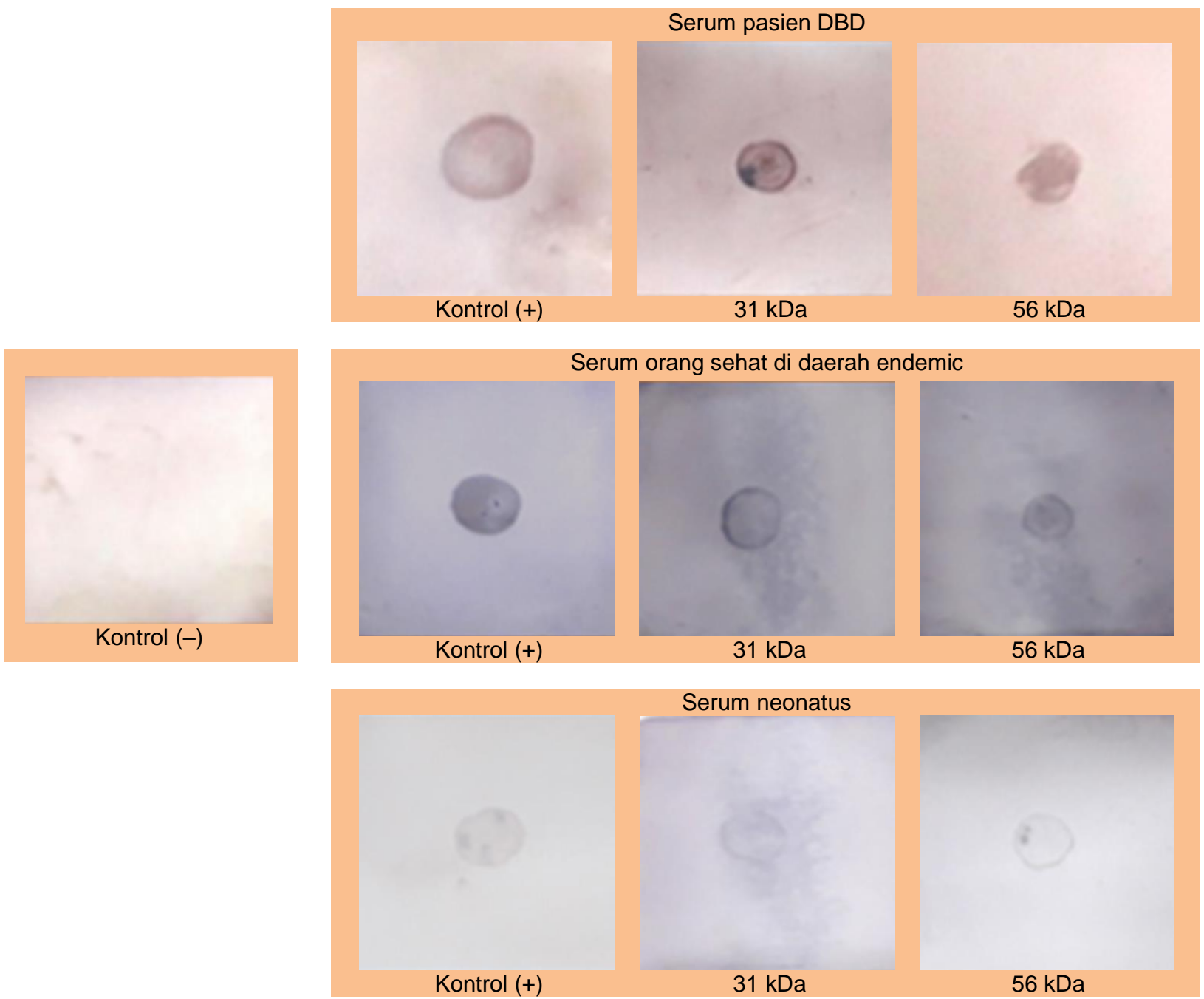

Gambar 7. Hasil analisis Dot Blot terhadap protein total, fraksi protein 31 dan 56 kDa hasil purifikasi dari kelenjar saliva Ae. aegypti. (Scanner Canon MP287) 
sampel serum membuktikan bahwa orang yang tinggal di daerah endemik memiliki respon imun dengan membentuk antibodi spesifik untuk bereaksi dengan antigen. Hal ini sesuai dengan penelitian yang dilakukan oleh Oktarianti et al. (2014) bahwa protein dengan berat molekul 31 dan $56 \mathrm{kDa}$ dari kelenjar saliva Ae. aegypti bersifat imunogenik dan dapat memodulasi respon imun orang yang tinggal di daerah endemik.

\section{KESIMPULAN}

Purifikasi protein imunogenik 31 dan 56 kDa dari kelenjar saliva Ae. aegypti dapat dilakukan dengan metode elektroelusi dan dialisis. Hasil purifikasi telah berhasil dikonfirmasi melalui analisis SDS-PAGE yang menunjukkan adanya pita tunggal protein 31 dan $56 \mathrm{kDa}$ yang sejajar dengan kontrol positif protein total kelenjar saliva Ae. aegypti. Hasil purifikasi tersebut diperkuat dengan data analisis imunogenisitas protein imunogenik 31 dan $56 \mathrm{kDa}$ melalui analisis dot blot yang menunjukkan adanya reaksi positif antara antigen dan antibodi dengan terbentuknya noktah gelap pada membran PVDF.

\section{UCAPAN TERIMA KASIH}

Ucapan terima kasih kepada Lembaga Penelitian dan Pengabdian kepada Masyarakat (LP2M) Universitas Jember yang telah memberikan dukungan dana penelitian dan publikasi melalui Surat Keputusan Rektor No. 18382/UN25/LT/2019 dengan Surat Penugasan No. 4301/UN25.3.1/LT/2019 Hibah Reworking Skripsi/Thesis 2019.

\section{DAFTAR PUSTAKA}

Ahmad R (2012) Protein purification. InTech, Janeza Trdine 951000 Rijeka, Croatia. doi: $10.5772 / 1287$

Almeras L, Fontaine A, Belghazi M, Bourdon S, Boucomont-Chapeaublanc E, OrlandiPradines E, Baragatti M, Corre-Catelin N, Reiter P, Pradines B, Fusai T, Rogier C (2010) Salivary gland protein repertoire from Aedes aegypti mosquitoes. Vector Borne Zoonotic Dis 10:391-402. doi: 10.1089/vbz.2009.0042

Andrew J, Bar A (2013) Morphology and morphometry of Aedes aegypti adult mosquito. Ann Rev Res Biol 3:52-69
Bano S, Lateef M, lqbal S, Naqvi B, lqbal L (2014) Role of protein denaturing agents and EDTA on $\alpha$-amylase activity from Bacillus subtilis Kibge Has. Int J Pharm Chem Biol Sci 4:411-415

Barbosa P, Berry DL, Kary CS (2015) Insect histology: Practical laboratory techniques, 1st edn. John Wiley \& Sons Ltd, West Sussex, UK. doi: 10.1002/9781118876114

Berger ST, Ahmed S, Muntel J, Polo NC, Bachur R, Kentsis A, Steen J, Steen H (2015) MStern blotting-high throughput polyvinylidene fluoride (PVDF) membrane-based proteomic sample preparation for 96-well plates. Mol Cell Proteomics 14:2814-2823. doi: 10.1074/mcp.0115.049650

Bhaskar S, Dutt S, Mukherjee R (2008) A simple method of electroelution of individual protein bands from SDS polyacrylamide gels for direct study in cellular assays. J Immunoassay 21:355375. doi: 10.1080/01971520009349542

Bhatt S, Gething PW, Brady OJ, Messina JP, Farlow AW, Moyes CL, Drake JM, Brownstein JS, Hoen AG, Sankoh O, Myers MF, George DB, Jaenisch T, Wint GR, Simmons CP, Scott TW, Farra JJ, Hay SI (2013) The global distribution and burden of dengue. Nature 496:504-507. doi: 10.1038/nature12060

Boesri H (2011) Biologi dan peranan Aedes albopictus (Skuse) 1894 sebagai penular penyakit. Aspirator 3:117-125. doi: 10.22435/aspirator.v3i2.2966

Burgess RR (2009) Elution of protein from gels. Methods Enzymol 463:565-572. doi: 10.1016/S0076-6879(09)63032-9

Chau TNB, Hieu NT, Anders KL, Wolbers M, Lien le B, Hieu LT, Hien TT, Hung NT, Farrar J, Whitehead S, Simmons CP (2009) Dengue virus Infections and maternal antibody decay in a prospective birth cohort study of Vietnamese Infants. J Infect Dis 200:1893-1900. doi: 10.1086/648407

de Melo BMS, da Silva NLL, Gomez RS, Navegantes KC, Oliveira ALB, Almeida L, Azevedo CHM, Monteiro MC (2015) Bioactive compounds of the salivary glands from Aedes aegypti with antihemostatic action. Ann Res Rev Biol 8:1-17. doi: 10.9734/ARRB/2015/20322 Dong F, Fu Y, Li X, Jiang J, Sun J, Cheng X 
(2012) Cloning, expression, and characterization of salivary apyrase from Aedes albopictus. Parasitol Res 110:931-937. doi: 10.1007/s00436$011-2579-x$

Farjana T, Tuno N (2013) Multiple blood feeding and host-seeking behavior in Aedes aegypti and Aedes albopictus (Diptera: Culicidae). J Med Entomol 50:838-846. doi: 10.1603/ME12146

Farnesi LC, Brito JM, Linss JG, PelajoMachado $M$, Valle $D$, Rezende $G L$ (2012) Physiological and morphological aspects of Aedes aegypti developing larvae: Effects of the chitin synthesis inhibitor novaluron. PLoS One 7:e30363. doi:

10.1371./journal.pone.0030363

Fontaine A, Diouf I, Bakkali N, Misse D, Pages F, Fusai T, Rogier C, Almeras L (2011) Implication of haematophagous arthropod salivary proteins in hostvector interactions. Parasites Vectors 4:187. doi: 10.1186/1756-3305-4-187

Guzman MG, Halstead SB, Artsob H, Buchy P, Farrar J, Gubler DJ, Hunsperger E, Kroeger A, Margolis HS, Martínez E, Nathan MB, Pelegrino JL, Simmons C, Yoksan S, Peeling RW (2010) Dengue: A continuing global threat. Nat Rev Microbiol 8:S7-16. doi: 10.1038/nrmicro2460

Haney P, Herting K, Smith S (2013) Molecular weight cut-off (MWCO) specifications and rates of buffer exchange with SlideA-Lyzer dialysis devices and snakeskin dialysis tubing. Protein Biology Resource Library, ThermoFisher Scientific, Waltam

Hedhammar M, Karlström AE, Hober S (2010) Chromatographic methods for protein purification. Royal Institute of Technology, Stockholm

Hodijah DN, Prasetyowati H, Marina R (2015) Tempat perkembangbiakan Aedes spp. sebagai penular virus dengue pada berbagai tempat di Kota Sukabumi. J Ekologi Kesehat 14:1-7. doi: 10.22435/jek.v14i1.4651.1-7

Juhn J, Naeem-Ullah U, Guedes BAM, Majid A, Coleman J, Pimenta PFP, Akram W, James AA, Marinotti O (2011) Spatial mapping of gene expression in the salivary glands of the dengue vector mosquito, Aedes aegypti. Parasites
Vectors 4:1. doi: 10.1186/1756-3305-4-1

Kazimírová M, Štibrániová I (2013) Tick salivary compounds: Their role in modulation of host defences and pathogen transmission. Front Cell Infect Microbiol 3:43. doi: 10.3389/fcimb.2013.00043

Londono-Renteria B, Cardenas JC, Cardenas LD, Christofferson RC, Chisenhall DM, Wesson DM, McCracken MK, Carvajal D, Mores CN (2013) Use of anti-Aedes aegypti salivary extract antibody concentration to correlate risk of vector exposure and dengue transmission risk in Colombia. PLoS One 8:e81211. doi: $10.1371 /$ journal.pone.0081211

Luplertlop N (2014) Aedes mosquito salivary immune peptides: Boost or block dengue viral infections. J Coastal Life Med 2:163168. doi: 10.12980/JCLM.2.2014C1219

Miller N (2010) Recent progress in dengue vaccine research and development. Curr Opin Mol Ther 12:31-38

Murrell S, Wu SC, Butler M (2011) Review of dengue virus and the development of a vaccine. Biotechnol Adv 29:239-247. doi: 10.1016/j.biotechadv.2010.11.008

Oktarianti R, Senjarini K, Fatchiyah F, Aulanni'am (2014) Immunogenic protein from salivary gland of Aedes aegypti against to human sera. Adv Nat Appl Sci 8:101-107

Oktarianti R, Senjarini K, Hayano T, Fatchiyah F, Aulanni am (2015) Proteomic analysis of immunogenic protein from salivary glands of Aedes aegypti. J Infect Public Health 8:575582. doi: 10.1016/j.jiph.2015.04.022

Rahayu DF, Ustiawan A (2013) Identifikasi Aedes aegypti dan Aedes albopictus. Balaba 9:7-10

Raquin V, Lambrechts L (2017) Dengue virus replicates and accumulates in Aedes aegypti salivary glands. Virology 507:7581. doi: 10.1016/j.virol.2017.04.009

Ribeiro JMC, Martin-Martin I, Arcà B, Calvo E (2016) A deep Insight into the sialome of male and female Aedes aegypti mosquitoes. PLoS One 11:e0151400. doi: 10.1371/journal.pone.0151400

Sa-Pereira P, Duarte J, Costa-Ferreira M (2000) Electroelution as a simple and fast protein purification method: Isolation of an extracellular xylanase from Bacillus sp. CCMI 966. Enzyme Microb Technol 27:95-99. doi: 
10.1016/s0141-0229(00)00185-x

Sasmono RT, Taurel AF, Prayitno A, Sitompul H, Yohan B, Hayati RF, Bouckenooghe A, Hadinegoro SR, Nealon J (2018) Dengue virus serotype distribution based on serological evidence in pediatric urban population in Indonesia. PLoS Negl Trop Dis 12:e0006616.

doi:

10.1371/journal.pntd.0006616

Sattayasai N (2012) Protein purification. Intech, Rijeka, Croatia. doi: $10.5772 / 35425$

Schmid MA, Kauffman E, Payne A, Harris E, Kramer LD (2017) Preparation of mosquito salivary gland extract and intradermal inoculation of mice. Bio-Protoc 7:e2407. doi: 10.21769/BioProtoc.2407

Sim S, Dimopoulos G (2010) Dengue virus inhibits immune responses in Aedes aegypti cells. PLoS One 5:e10678. doi: 10.1371/journal.pone.0010678

Sucipto CD (2011) Vektor penyakit tropis. Gosyen Publishing, Yogyakarta

Urdaneta-Marquez L, Failloux AB (2011) Population genetic structure of Aedes aegypti, the principal vector of dengue viruses. Infect Genet Evol 11:253-261. doi: 10.1016/j.meegid.2010.11.020

Vázquez-Iglesias L, Estefanell-Ucha B, Barcia-Castro L, de la Cadena MP, Alvarez-Chaver $P$, Ayude-Varquez D, Rodriguez-Berrocal FJ (2017) A simple electroelution method for rapid protein purification: isolation and antibody production of alpha toxin from
Clostridium septicum. PeerJ 5:e3407. doi: 10.7717/peerj.3407

Vogt MB, Lahon A, Arya RP, Kneubehi AR, Spencer Clinton JL, Paust S, RiccoHesse R (2018) Mosquito saliva alone has profound effects on the human immune system. PLoS Negl Trop Dis 12:e0006439. doi: 10.1371/journal.pntd.0006439

Wan SW, Lin CF, Wang S, Chen YH, Yeh TM, Liu HS, Anderson R, Lin YS (2013) Current progress in dengue vaccines. $J$ Biomed Sci 20:37. doi: 10.1186/14230127-20-37

Wasinpiyamongkol L, Patramool S, Luplertlop $N$, Surasombatpattana $P$, Doucoure $S$, Mouchet $F$, Seveno $M$, Remoue $F$, Demettre $E$, Brizard JP, Jouin $P$, Biron DG, Thomas F, Misse' D (2010) Bloodfeeding and immunogenic Aedes aegypti saliva proteins. Proteomics 10:1906-1916. doi: 10.1002/pmic.200900626

Yung CF, Lee KS, Thein TL, Tan LK, Gan VC, Wong JGX, Lye DC, Ng LC, Leo YS (2015) Dengue serotype-specific differences in clinical manifestation, laboratory parameters and risk of severe disease in adults, Singapore. Am J Trop Med Hyg 92:999-1005. doi: 10.4269/ajtmh.14-0628

Zettel C, Kaufman P (2013) Yellow fever mosquito Aedes aegypti (Linnaeus) (Insect: Diptera: Culicidae). EENY-434. Entomology and Nematology Department, UF/IFAS Extension, Florida 